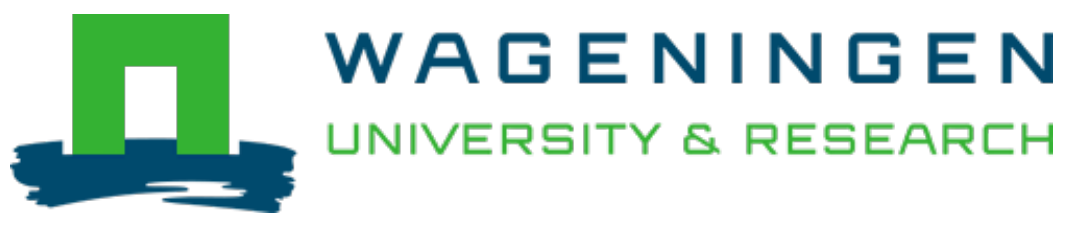

\title{
The diversity of autochthonous roses in Flanders (Belgium) in the view of the European generose reference framwork
}

\author{
Acta Horticulturae \\ Cock, K.; Breyne, P.; Nybom, H.; Smulders, M.J.M.; Slycken, J. et al \\ https://doi.org/10.17660/ActaHortic.2007.760.88
}

This article is made publicly available in the institutional repository of Wageningen University and Research, under the terms of article $25 \mathrm{fa}$ of the Dutch Copyright Act, also known as the Amendment Taverne. This has been done with explicit consent by the author.

Article 25 fa states that the author of a short scientific work funded either wholly or partially by Dutch public funds is entitled to make that work publicly available for no consideration following a reasonable period of time after the work was first published, provided that clear reference is made to the source of the first publication of the work.

This publication is distributed under The Association of Universities in the Netherlands (VSNU) 'Article $25 \mathrm{fa}$ implementation' project. In this project research outputs of researchers employed by Dutch Universities that comply with the legal requirements of Article $25 \mathrm{fa}$ of the Dutch Copyright Act are distributed online and free of cost or other barriers in institutional repositories. Research outputs are distributed six months after their first online publication in the original published version and with proper attribution to the source of the original publication.

You are permitted to download and use the publication for personal purposes. All rights remain with the author(s) and / or copyright owner(s) of this work. Any use of the publication or parts of it other than authorised under article $25 \mathrm{fa}$ of the Dutch Copyright act is prohibited. Wageningen University \& Research and the author(s) of this publication shall not be held responsible or liable for any damages resulting from your (re)use of this publication.

For questions regarding the public availability of this article please contact openscience.library@,wur.nl 


\title{
The Diversity of Autochthonous Roses in Flanders (Belgium) in the View of the European GENEROSE Reference Framework
}

\author{
K. De Cock $^{1,2}$, K. Vander Mijnsbrugge ${ }^{2}$, P. Breyne ${ }^{2}$, H. Nybom ${ }^{3}$, M.J.M. Smulders ${ }^{4}$, \\ J. Van Slycken ${ }^{2}$ and J. De Riek ${ }^{1}$ \\ ${ }^{1}$ Institute for Agricultural and Fisheries Research (ILVO), Plant Unit - Applied Genetics \\ and Breeding, Caritasstraat 21, B-9090 Melle, Belgium \\ ${ }^{2}$ Research Institute for Nature and Forest, Kliniekstraat 25, B-1070 Brussel, Belgium \\ ${ }^{3}$ Balsgård-Department of Crop Science, Swedish University of Agricultural Sciences, \\ Fjälkestadsvägen 459 SE-291 94 Kristianstad, Sweden \\ ${ }^{4}$ Plant Research International, PO Box 16, NL-6700 AA Wageningen, The Netherlands
}

Keywords: AFLP, Canina, dog roses, genetic variation, hybridisation, Rosa, taxonomy

\begin{abstract}
The subgenus Rosa is very intriguing but complex. Nowadays, many European taxonomists apply the taxonomical structure of Henker (2000), although other classifications and views are still considered. In order to gain insight in the taxonomical structure, 1,144 individuals belonging to 27 different wild rose species and some spontaneous hybrids were sampled in Belgium, France, Germany, The Netherlands and Scandinavian countries. Using AFLP analysis, the intra- and interspecific genetic variation was evaluated. PCO analysis supported the major subdivision of the subgenus Rosa in different sections and subsections according to Henker (2000). However, the position of $R$. tomentella in a separate subsection or within the subsection Caninae is questioned. In order to support the preservation and use of autochthonous genetic resources the genetic fingerprints of several populations were compared. It is concluded that wild populations of rare or locally prevailing species, accessioned from different regions, show genetic differentiation. However, for the common and welldispersed species no differentiation was found.
\end{abstract}

\section{INTRODUCTION}

Since the beginning of the nineties, interest in autochthonous genetic resources increased in Europe. A plant is autochthonous if it is regenerated only naturally since the last glaciation or, if propagated artificially, only with strict local material (Kleinschmit et al., 2004). An autochthonous Swedish $R$. canina plant, for example, is considered allochthonous in Belgium. As a consequence of the local character of the plant, we assume that autochthonous individuals or populations are adapted to local ecological conditions. During the past century autochthonous plant populations were exposed to men-induced stress, such as increasing habitat fragmentation and import of allochthonous seeds of native species from foreign countries.

Several initiatives were taken to make an inventory for autochthonous genetic resources of woody species throughout Europe (Vander Mijnsbrugge et al., 2005). These inventories are only the first step in a global project to preserve and use these genetic resources. The inventory ordered by the Flemish community showed that Flanders, the densely populated Northern part of Belgium, still contains unexpected and interesting autochthonous genetic resources.

The complexity of the genus Rosa was already mentioned by Linneaus (1753) due to a lack of boundaries between the species and the absence of species specific characteristics resulting from interspecific hybridization (Wissemann and Hellwig, 1997). Determination of the status of hybrids is problematic due to a sympatric growth of putative parental species along with introgressants expressing mosaic characteristics which are not observed in the parental taxa (Rieseberg and Ellstrand, 1993; Werlemark and Nybom, 2001). In addition, the unique and mostly pentaploid chromosome constitution of the dog roses (Henker, 2000; Darlington and Wylie, 1961) and consequently the development of an alternative type of meiosis, named the Canina 
meiosis (Blackburn and Heslop-Harrison, 1921; Täckholm, 1920, 1922) ended in the complex determination of wild individuals. Due to this Canina meiosis, descendents receive four chromosome sets from the maternal and only one from the paternal genome, making up a new pentaploid individual (Werlemark and Nybom, 2001).

The variety of classification systems and species concepts defined since Linneaus (1753) reflect the complexity of the subsection Caninae. Nowadays, the taxonomical structure of Henker (2000) is widely used on the continent, although sometimes small adaptations are made. He suggested the division of the subgenus Rosa into five sections: Pimpinellifolia, Rosa, Caninae, Cinnamomeae and Synstylae, and divided the section Caninae into the subsections Trachyphyllae, Rubrifolia, Rubigineae, Vestitae, Tomentellae and Caninae (Table 1).

In this paper we want to 1) quantify the genetic diversity within and between autochthonous sections, subsections and species in order to gain insight in the taxonomical structure of the wild European species, 2) investigate the intraspecific variation of populations sampled in different countries and regions in order to identify and characterize the more diverse and valuable populations.

The results presented in this paper are mostly from the EU-funded GENEROSE project (Van Huylenbroeck et al., 2005), focusing on the conservation and use of natural resources in the species Rosa. In addition, a closer look was taken at the genetic variation within and between the Flemish autochthonous species and populations.

\section{MATERIALS AND METHODS}

\section{Plant Material}

A total of 390 populations belonging to 27 different wild rose species and some spontaneous hybrids were sampled in Europe (Table 1). From each population 5 individuals were randomly sampled during spring and summer. Focussing on Flanders, a total of 481 Flemish autochthonous roses were analysed divided over 46 different populations, each containing 30 individuals, and belonging to 10 autochthonous species and one wild hybrid. The sampling sites were based on Thomaes et al. (2004).

\section{Genetic Analysis}

Young and fresh leaves were collected in the field and immediately frozen in liquid nitrogen, freeze-dried and stored under vacuum conditions. DNA was isolated using Qiagen DNeasy Plant Mini Kit (Westburg, Netherlands) according to the manufacturer's instructions. The AFLP reactions were performed according to Vos et al. (1995), with some modifications. Three hundred ng of DNA was cut with the restriction enzymes EcoI and MseI (Life Technologies). Digestion and ligation of the adapters was performed in a single reaction for 4 hours at $37^{\circ} \mathrm{C}$. Afterwards the samples were stored at $4^{\circ} \mathrm{C}$. The preamplification step was performed with a EcoI primer and a MseI primer containing one additional selective nucleotide. Final amplifications were performed with primers carrying three selective nucleotides. The three primer combinations used were selected based on their scorability, number of polymorphisms between species and individuals. Fragment separation was performed on the Global Edition IR $^{2}$ system van LICOR (LI-COR). Polymorphic bands were scored in the range of 90 to $650 \mathrm{bp}$.

\section{Statistical Analysis}

The binary output was imported in S-Plus 6.2 Professional (Insightful Corporation) and converted to a genetic distance matrix using the Jaccard coefficient, and a principle coordinate analysis (PCO) was performed. Based on the mean population frequency, a simulation was repeated 100 times in order to replace missing or not scorable markers. A comparison between three randomly chosen simulated datasets and the dataset including only the completely scored individuals showed comparable outcomes (Table 2). Further analyses were based on a randomly chosen simulated dataset. 


\section{RESULTS}

Taxonomical Structure

1. The Subgenus Rosa. Using a simulated dataset, the first three components explained $41 \%$ of the variation present in the dataset (Table 2). Based on the first two axes (Fig. 1), the several sections and subsections within the subgenus Rosa could be recognized (Table $1)$. The first cluster was formed by the sections Pimpinellifolia (R. spinosissima), and Cinnamomeae ( $R$. pendulina, $R$. majalis), the second contained individuals from the section Caninae, subsection Vestitae (R. villosa, R. mollis), and the section Synstylae ( $R$. arvensis). Another cluster contained individuals of the section Rosa ( $R$. gallica). Finally, the section Caninae formed the largest and most dense cluster, with the major subsections Rubigineae ( $R$. rubiginosa, $R$. micrantha, $R$. agrestis, $R$. elliptica, $R$. inodora), Caninae $(R$. canina, $R$. corymbifera, $R$. dumalis, $R$. caesia, $R$. stylosa, $R$. subcanina, $R$. subcollina, $R$. montana), Tomentellae ( $R$. tomentella) and Vestitae $(R$. pseudoscabriuscula, $R$. tomentosa, $R$. villosa, $R$. mollis). The presence of the subsections Trachyphyllae and Rubrifolia in this dataset is too rare to be put in a global picture.

2. The Section Caninae. Focussing on the dense cluster, analyses were repeated only including the individuals of the largest subsections of the section Caninae, more specifically Rubigineae, Vestitae, Caninae and Tomentellae. The first three axes explained $40 \%$ of the variation present in the dataset. According to the first two components (Fig. 2a), only the subsection Rubigineae was subdivided.

Next, the subsection Rubigineae was excluded and the analyses were repeated. The subsection Vestitae was subdivided from the two large remaining subsections Caninae and Tomentellae (Fig. 2b). In this biplot, $27 \%$ of the variation was explained. The subsections Caninae and Tomentellae could not be subdivided using this method, although the first two axes also explained $27 \%$ of the variation.

\section{Intraspecific Variation}

For the most common and well-dispersed rose species in Europe, e.g. $R$. canina and $R$. rubiginosa, no intraspecific differentiation was found. In contrast, the less common and rather local species, e.g. $R$. arvensis, $R$. gallica and $R$. jundzilii showed intraspecific variation both between and within countries (Fig. 3). Furthermore, the populations of $R$. arvensis sampled at different regions within Belgium showed also a tendency towards genetic differentiation.

\section{DISCUSSION}

The large subdivision analyzed by AFLP agreed with that of Henker (2000), who based his structure on both the morphological similarities and dissimilarities between the different species and on their state of ploidy and type of meiosis. Focussing on the complex and polymorphic section Caninae, the large subsections are morphological easily recognised. The Rubigineae are characterized by very sticky leaflets with numerous glands that spread apple fragrance, while the leaflets of the Vestitae are conspicuously hairy on both sides. $R$. tomentella, the only representative of the subsection Tomentellae, has pubescent and glanded midribs and veins, mostly the lower surface of the leaflet is completely covered with glands and hairs. In contrast, within the subsection Caninae the leaflets vary from glabrous to hairy and different parts of the leaflets or hips vary from eglandular to sparely glanded (Henker, 2000). Consequently, the morphological differences between the two latter subsections are more subtle and the presence of $R$. tomentella in the subsection Tomentellae is sometimes questioned.

The subsection Rubigineae is the most distinct group within the section Caninae, followed by the Vestitae. However, it was not possible to distinguish between the subsections Tomentellae and Caninae. This clustering supports the subdivision of the section Caninae in several subsections, although subdivision of the subsection Tomentellae is not supported. Perhaps it is better to position $R$. tomentella within the subsection Caninae as some taxonomists already did (Thomaes et al., 2004). 
The lack of intraspecific differentiation within common and well-dispersed rose species might be due to the presence of a meta-population where migration of pollen and seeds is possible among populations. Within some less common or locally abundant species, intraspecific variation was found between populations of different countries but also between different regions within one country. This intraspecific variation is worth to preserve if it is a local adaptation of the plant or of the population, if the introgression of maladapted (non-local) genes reduces the fitness of the local population or if the introduction of a non-local gene pool leads to a reduction of the species biodiversity.

\section{ACKNOWLEDGMENTS}

Thanks to all the lab technicians for their work in the lab, Paul Quataert and Pieter Verschelde for their statistical support and several colleagues for help with sampling. These studies has been carried out with financial support from the Flemish Community (Agency for Nature and Forest) and from the Commission of the European Communities, specific Research Programme "Quality of Life and Management of Living Resources", QLRT-2001-01278 "Genetic evaluation of European rose resources for conservation and horticultural use". It does not reflect its views and in no way anticipates the Commission's future policy in this area.

\section{Literature Cited}

Blackburn, K.B. and Heslop-Harrison, J.W. 1921. The status of the British rose forms as determined by their cytological behaviour. Ann. Bot. 35(85): 159-188.

Darlington, C.D. and Wylie, A.P. 1961. Chromosome atlas of flowering plants. George Allen \& Unwin Ltd, London.

Henker, H. 2000. Rosa. In: Gustav Hegi, Illustrierte Flora von Mittel-Europa, Band IV, Teil 2C, Lieferung A.2. Auflage. Parey Buchverlag im Blackwell Wissenschaftsverlag $\mathrm{GmbH}$, Berlin.

Kleinschmit, J.R.G., Kownatzki, D. and Gregorius, H.R. 2004. Adaptational characteristics of autochthonous populations-consequences for provenance delineation. Forest Ecology and Management. 197: 213-224

Linneaus, C. 1753. Species Plantarum. Holmiae. Tomus. 1: 491-492.

Rieseberg, L.H. and Ellstrand, N.C. 1993. What can molecular and morphological markers tell us about plant hybridisation? Crit. Rev. Plant Sci. 12(3)-213-241.

Täckholm, G. 1920. On the cytology of the genus Rosa. A preliminary note. Svensk Bot. Tidskr. 14: 300-311.

Täckholm, G. 1922. Zytologische Studien über die Gattung Rosa. Acta Horti Berg. 7(3): 97-381.

Thomaes, A., Vander Mijnsbrugge, K. and De Cock, K. 2004. Taxonomie, ecologie en verspreiding van inheemse rozen in Vlaanderen. Rapport IBW Bb R 2004.020. Instituut voor Bosbouw en Wildbeheer, Geraardsbergen.

Vander Mijnsbrugge, K., Cox, K. and Vanslycken, J. 2005. Conservation Approaches For Autochthonous Woody Plants in Flanders. Silvae Genetica. 54:4-5.

Van Huylenbroeck, J., Smulders, M.J.M, Debener, T., Nybom, H., Gudin, S., Cox, P., Crespel, L. and De Riek, J. 2005. GENEROSE: Genetic Evalutation of European Rose Resources for Conservation and Horticultural Use. Acta Hort. 690: 119-123.

Vos, P., Hogers, R., Bleeker, M., Reijans, M., van de Lee, T., Hornes, M., Frijters, A., Pot, J., Peleman, J., Kuiper, M. and Zabeau,M. 1995. AFLP: a new technique for DNA fingerprinting. Nucleic Acids Research. 23(21): 4407-4414.

Werlemark, G. and Nybom, H. 2001. Skewed distribution of morphological character scores and molecular markers in three interspecific crosses in Rosa section Caninae. Hereditas. 134: 1-13.

Wissemann, V. and Hellwig, F.H. 1997. Reproduction and hybridisation in the Genus Rosa, section Caninae (Ser.) Rehd. Bot. Acta. 110: 251-256. 


\section{$\underline{\text { Tables }}$}

Table 1. Taxonomical overview of the European autochthonous species of the genus Rosa based on Henker (2000). Indicated are: P: ploidy (Henker, 2000; *: Darlington and Wylie, 1961); number of individuals sampled in Belgium (B), France (F), Germany $(\mathrm{G})$, The Netherlands (N), Scandinavian countries (S).

\begin{tabular}{|c|c|c|c|c|c|c|c|}
\hline \multirow{2}{*}{\multicolumn{8}{|c|}{$\begin{array}{l}\text { Genus Rosa } \\
\text { Section Pimpinellifolia }\end{array}$}} \\
\hline & & & & & & & \\
\hline R. spinosissima & $4 \mathrm{x}$ & 8 & 11 & 19 & 23 & 0 & 61 \\
\hline Section Rosa & & & & & & & \\
\hline R. gallica & $4 \mathrm{x}$ & 0 & 39 & 10 & 0 & 0 & 49 \\
\hline \multicolumn{8}{|l|}{ Section Caninae } \\
\hline Subsection Trachyphyllae & & & & & & & \\
\hline $\begin{array}{c}\text { R. jundzillii } \\
\text { Subsection Rubrifolia }\end{array}$ & $6 x$ & 0 & 0 & 10 & 0 & 0 & 10 \\
\hline $\begin{array}{l}\quad R . \text { glauca }=\text { R. rubrifolia } \\
\text { Subsection Vestitae }\end{array}$ & $4 \mathrm{x}$ & 1 & 7 & 8 & 0 & 0 & 16 \\
\hline R. tomentosa & $5 \mathrm{x}$ & 3 & 4 & 0 & 56 & 0 & 63 \\
\hline R. pseudoscabriuscula & $5 \mathrm{x}$ & 23 & 0 & 5 & 1 & 0 & 29 \\
\hline R. sherardii & $4 x, 5 x, 6 x$ & 0 & 1 & 11 & 10 & 6 & 28 \\
\hline R. mollis & $4 x, 5 x, 6 x$ & 0 & 0 & 12 & 0 & 18 & 30 \\
\hline R. villosa & $4 \mathrm{x}$ & 2 & 2 & 0 & 0 & 0 & 4 \\
\hline \multicolumn{8}{|l|}{ Subsection Rubigineae } \\
\hline R. rubiginosa & $5 \mathrm{x}$ & 25 & 5 & 18 & 35 & 43 & 126 \\
\hline R. micrantha & $4 x, 5 x, 6 x$ & 6 & 0 & 5 & 14 & 0 & 25 \\
\hline R. elliptica & $5 x, 6 x$ & 0 & 4 & 5 & 2 & 0 & 11 \\
\hline R. agrestis & $5 x, 6 x$ & 10 & 9 & 0 & 10 & 0 & 29 \\
\hline R. inodora & $5 x, 6 x$ & 0 & 0 & 0 & 0 & 8 & 8 \\
\hline \multicolumn{8}{|l|}{ Subsection Tomentellae } \\
\hline \multicolumn{8}{|l|}{ Subsection Caninae } \\
\hline R. canina $($ R. pouzinii $)$ & $5 \mathrm{x}$ & 30 & 12 & 51 & 72 & 42 & 207 \\
\hline R. corymbifera & $5 x$ & 10 & 7 & 34 & 60 & 0 & 111 \\
\hline R. dumalis & $5 x, 6 x$ & 0 & 5 & 5 & 4 & 52 & 62 \\
\hline R. caesia & $5 x, 6 x$ & 4 & 2 & 1 & 3 & 4 & 14 \\
\hline R. subcanina & $5 x$ & 2 & 0 & 1 & 6 & 0 & 9 \\
\hline R. subcollina & $5 x$ & 0 & 0 & 0 & 11 & 0 & 11 \\
\hline R. montana & $5 x$ & 0 & 10 & 0 & 0 & 0 & 10 \\
\hline R. stylosa & $5 x, 6 x$ & 4 & 0 & 0 & 0 & 0 & 4 \\
\hline \multicolumn{8}{|l|}{ Section Cinnamomeae } \\
\hline R. pendulina & $4 \mathrm{x}$ & 0 & 2 & 10 & 0 & 0 & 12 \\
\hline R. majalis & $2 x, 4 x, 8 x$ & 0 & 0 & 21 & 0 & 8 & 29 \\
\hline \multicolumn{8}{|l|}{ Section Synstylae } \\
\hline R. arvensis & $2 \mathrm{x}$ & 15 & 6 & 36 & 12 & 0 & 69 \\
\hline R. sempervirens & $2 x^{*}$ & 0 & 8 & 0 & 0 & 0 & 8 \\
\hline
\end{tabular}


Table 2. Comparison of the percentage of the variation explained by the first three components (Comp 1, 2 and 3) of the original and the randomly chosen datasets. Total: cumulative percentage of the first three components.

\begin{tabular}{lcccc}
\hline Dataset & Comp.1 & Comp.2 & Comp.3 & Total \\
\hline Original & $18 \%$ & $16 \%$ & $11 \%$ & $45 \%$ \\
Simulation 014 & $20 \%$ & $11 \%$ & $10 \%$ & $41 \%$ \\
Simulation 048 & $20 \%$ & $11 \%$ & $10 \%$ & $41 \%$ \\
Simulation 098 & $20 \%$ & $11 \%$ & $10 \%$ & $41 \%$ \\
\hline
\end{tabular}

\section{Figures}

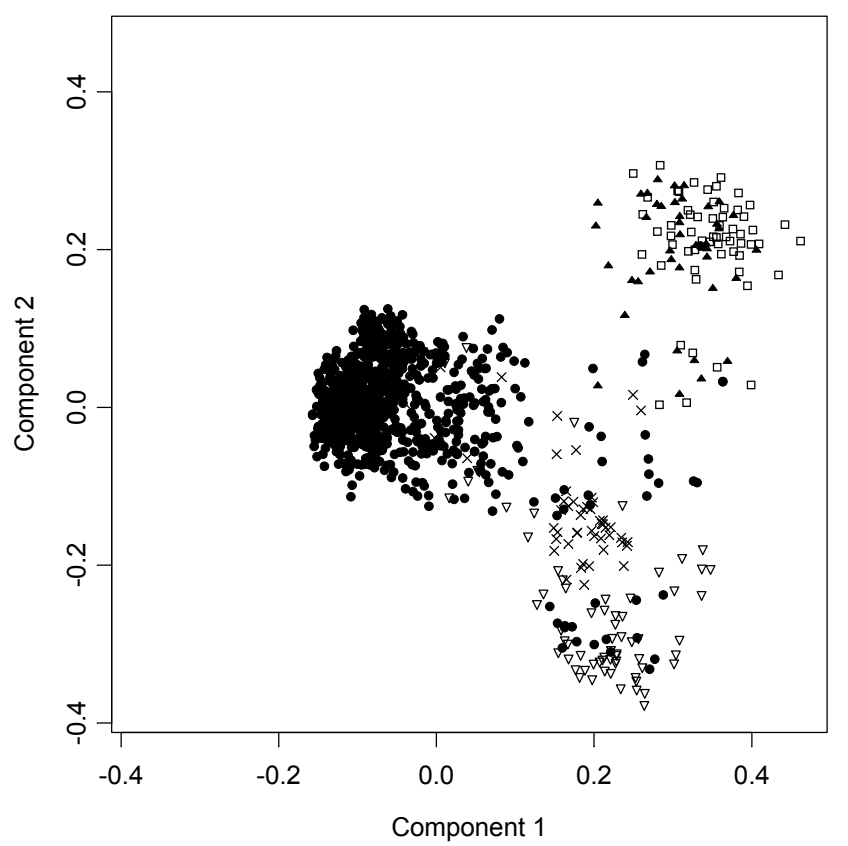

Fig. 1. Biplot of the first two Principle Components of the subgenus Rosa based on AFLP markers. Symb: ㅁ: Pimpinellifolia; X: Rosa; •: Caninae; $\mathbf{\Delta}$ : Cinnamomeae; $\nabla:$ Synstylae. 

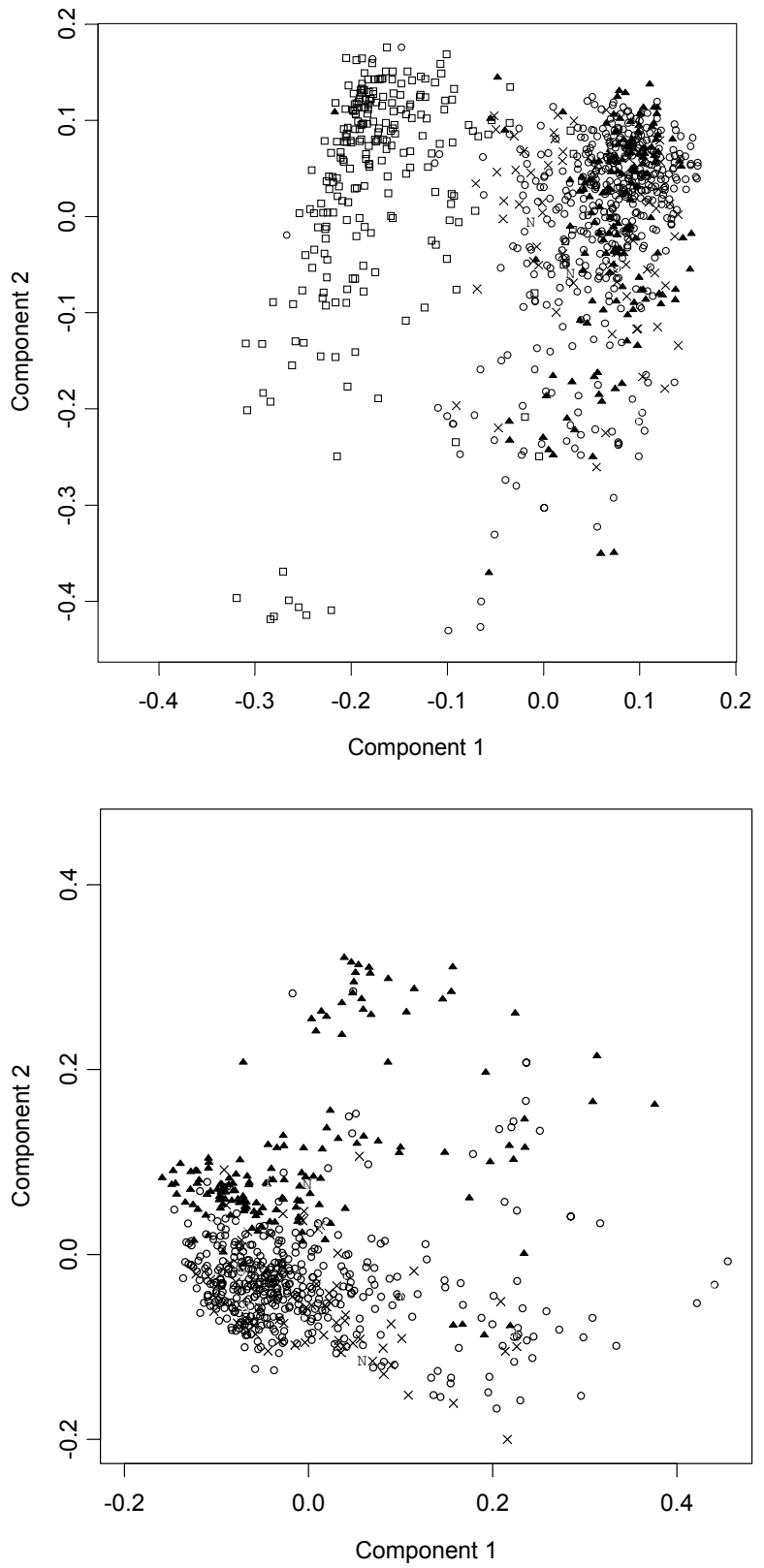

Fig. 2. Biplot of the first two Principle Components of (2a: above) the section Caninae and of ( $2 \mathrm{~b}$ : below) the section Caninae without the subsection Rubigineae based on AFLP markers. Symb: $\mathbf{\Delta}$ : Vestitae; $\mathbf{\square}$ : Rubigineae; X: Tomentellae; $\circ:$ Caninae. 


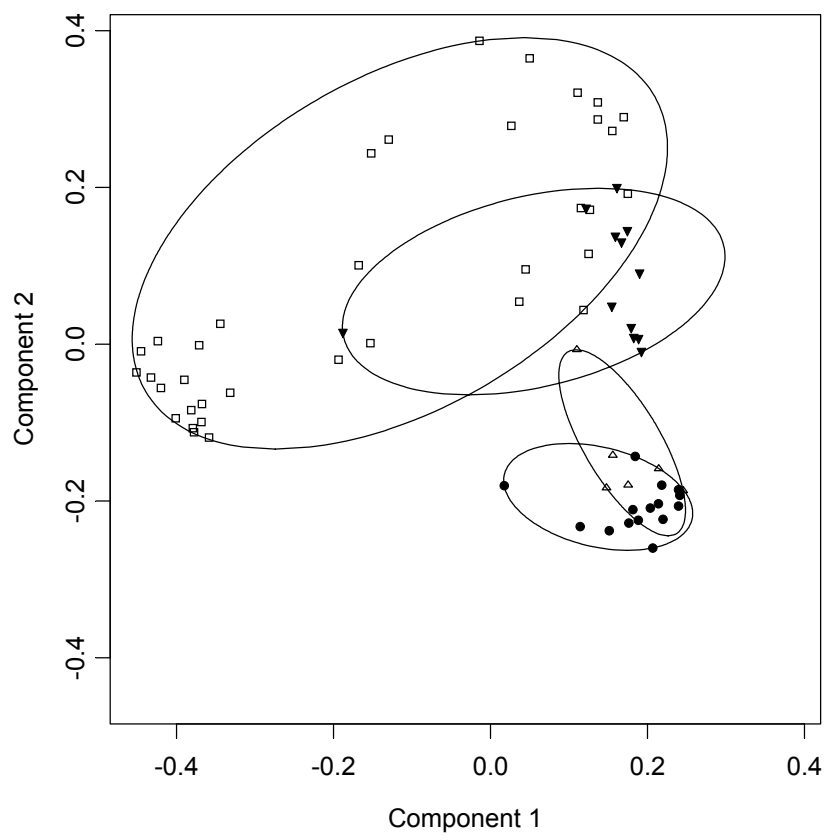

Fig. 3. Biplot of the first two Principle Components of R. arvensis showing intraspecific variation based on the origin of the individuals. Symb: Belgium: •; The Netherlands: $\mathbf{\nabla}$; France: $\Delta$; Germany: $\mathbf{\square}$. 